\title{
ANALISIS TINGKAT KESIAPAN GURU DALAM MENERAPKAN MATERI KEBENCANAAN PADA PROSES PEMBELAJARAN DI KABUPATEN KLATEN
}

\author{
Hastari Setyo Palupi 1), Mikko Wahyu Masution'2), Putri Ainur Rida ${ }^{3)}$, dan Meliyani4) \\ 1,23,4Program Studi Pendidikan Geografi, Fakultas Keguruan dan IImu Pendidikan, \\ Universitas Muhammadiyah Surakarta

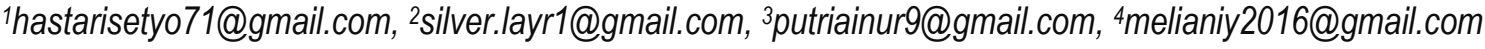

\begin{abstract}
Abstrak: Berbagai bencana di Indonesia sebagian besar terkait dengan proses geologi seperti gempabumi, vulkanisme, dan tsunami. Dilihat dari letak dan kondisi fisiknya, Indonesia merupakan negara yang memiliki risiko tinggi terjadinya bencana. Dengan maraknya bencana yang terjadi di Indonesia, maka tidak sedikit korban jiwa yang ditimbulkan, termasuk dari kalangan anak-anak usia sekolah. Oleh sebab itu, diperlukan kesiapan guru dalam menerapkan materi kebencanaan pada proses pembelajaran. Tujuan dari penelitian ini ialah mengetahui tingkat kesiapan guru dalam menerapkan materi kebencanaan di sekolah dan mengetahui pengaruh tingkat pendidikan serta umur guru dalam menerapkan materi kebencanaan di sekolah. Jenis penelitian ini adalah penelitian deskriptif kuantitatif dengan menggunakan metode observasi, wawancara dan kuesioner. Hasil dari penelitian ini menunjukan bahwa kesiapan guru dalam menerapkan materi kebencanaan di sekolah berada pada kategori tinggi, dibuktikan dengan angka persentase sebesar $72 \%$ dari keseluruhan populasi penelitian.
\end{abstract}

Kata kunci: kesiapan guru, materi kebencanaan, proses pembelajaran

\begin{abstract}
Various of disasters in Indonesia are related to geological processes such as earthquakes, volcanism and tsunamis. Viewed from geological location and physical condition, Indonesia is a country that has a high risk of disasters. With the rampant disasters occurring in Indonesia, there are not a few fatalities, including among school-age children. Therefore, teachers readiness is needed to applying disaster materials in the learning process. The purpose of this research is to study the level of teachers readiness to implementing disaster materials in schools and understand the level of education and age of teachers in implementing disaster materials in schools. This research is a quantitative descriptive study using the method of observation, interviews and questionnaires. The results of this study indicate that teachers readiness to implementing disaster materials in schools are in the high category, as evidenced by a precentage of $72 \%$ from the entire study population.
\end{abstract}

Keywords: disaster materials, learning process, teacher readiness

\section{PENDAHULUAN}

Bencana adalah sebuah peristiwa yang mengancam, mengganggu kehidupan dan penghidupan masyarakat yang disebabkan baik oleh faktor alam ataupun faktor non alam sehingga menimbulkan korban jiwa, kerugian harta benda, dampak psikologis dan gangguan kesehatan mental yang lebih kompleks (Undang-Undang Nomor 24 tahun 2007). Bencana merupakan suatu malapetaka yang luar biasa yang datang bisa kapan saja tanpa diduga waktunya dengan tepat (Honesti dan Djali, 2012). Dilihat dari letak dan kondisi fisiknya, Indonesia merupakan negara yang memiliki risiko tinggi terjadinya bencana karena secara geologis terletak pada pertemuan 3 lempeng, yaitu Lempeng Eurasia, IndoAustralia dan Lempeng Pasifik. Kondisi tersebut berpotensi menimbulkan bencana, dengan karakteristik yang berbeda di setiap wilayah Indonesia. Salah satu bencana yang mengancam di Indonesia adalah letusan gunung api dan gempabumi (Setyowati, et al, 2013).

Masyarakat yang terancam bencana sangat beragam, baik yang terdidik maupun yang belum pernah tersentuh pendidikan, semua perlu diberikan pemahaman pentingnya pengurangan risiko bencana melalui proses pembelajaran dalam pendidikan. Pendidikan merupakan salah satu cara yang 
dapat ditempuh untuk meningkatkan pengetahuan masyarakat terhadap adanya risiko bencana yang dapat terjadi kapan saja dan di mana saja. Bencana di sekolah dapat didefinisikan sebagai segala kejadian yang mengakibatkan titik balik, seringkali penderitaan, tekanan, atau ketidakteraturan fungsi secara fisik dan atau psikologis (Reeves, et al, 2010).

Pendidikan kebencanaan dapat diberikan melalui sistem pendidikan formal dan non formal yang bertujuan untuk mengubah pola pikir, sikap dan perilaku dalam upaya mengurangi risiko bencana serta menjadikan upaya pengurangan risiko bencana menjadi budaya masyarakat. Masih rendahnya pendidikan kebencanaan pada masyarakat di Indonesia dibuktikan dengan banyaknya kasus kehilangan atau rusaknya alat pemantau kebencanaan yang disediakan. Hal ini dapat mengakibatkan banyaknya kendala dalam pemantauan kebencanaan, seperti lambatnya informasi yang akan diteruskan pada masyarakat tentang terjadinya bencana.

Sekolah memegang peranan yang strategis dalam upaya pengurangan resiko bencana, hal tersebut dikarenakan sekolah merupakan sumber ilmu pengetahuan (Hafida, 2018). Sekolah mampu meningkatkan pengetahuan dan keterampilan siswa dalam menghadapi bencana. Pendidikan kebencanaan dapat dimulai pada saat penyampaian materi dalam proses pembelajaran. Penyampaian materi harus didukung dengan adanya tenaga pendidik atau seorang guru yang paham akan kondisi bencana serta wilayah mengajar. Hal ini sangat dibutuhkan guna meningkatkan pengetahuan peserta didik mengenai pengurangan risiko bencana. Adanya pendidikan kebencanaan di sekolah diharapkan dapat meminimalkan jumlah korban jiwa akibat bencana. Kesiapan seorang guru dalam menyampaikan materi kebencanaan dapat dimulai dari pembekalan tentang kebencanaan untuk peningkatan pengetahuan sadar terhadap bencana dengan sosialisasi dalam tujuan edukasi.

Kebijakan sekolah sangat berpengaruh terhadap keberadaan pendidikan kebencanaan dalam proses pembelajarannya. Kebijakan sekolah dirumuskan sebagai bentuk komitmen pemerintah terhadap Pengurangan Risiko Bencana (PRB) di bidang pendidikan, yang dikembangan atas dasar kondisi kebencanaan di Indonesia. Atas kondisi Indonesia yang rawan akan terjadinya bencana, maka kebijakan Pengurangan Risiko Bencana di Sekolah dianggap penting sebagai jalan baru untuk menhadapi bencana.

Penelitian ini dirancang dan dilaksanakan berdasarkan hasil penelitian-penelitian terdahulu yang pernah dilakukan dan bersifat relevan. Hasil-hasil dari penelitian tersebut tidak terlepas dari topik penelitian ini yaitu mengenai kesiapan guru dalam memberikan materi kebencanaan pada proses Pembelajaran. Lesmana \& Purborini (2015) misalnya melakukan penelitian dengan judul "Kesiapsiagaan Komunitas Sekolah Dalam Menghadapi Bencana di Kabupaten Magelang". Dalam penelitian tersebut disimpulkan bahwa implementasi sekolah siaga bencana sangatlah penting terutama di daerah rawan bencana. Rata-rata dari hampir semua parameter Sekolah Siaga Bencana (SSB) yang relatif kecil menandakan kesiapsiagaan komponen sekolah yang masih di bawah harapan. Hal ini dikarenakan masih barunya sosialisasi SSB. Dapat dilihat dari penelitian diatas, bahwa hasil menunjukan bagaimana penerapan sekolah siaga bencana dari segi parameter kesiapsiagaan komponen sekolah. Selain itu, Aprilin et al (2018) juga melakukan penelitian dengan judul "Kesiapsiagaan Sekolah Terhadap Potensi Bencana Banjir di SDN Gebangmalang Kecamatan Mojoanyar Kabupaten Mojokerto". Penelitian ini menghasilkan kesimpulan bahwa tingkat pengetahuan guru dan orangtua di SDN Gebangmalang Kecamatan Mojoanyar Kabupaten Mojokerto terhadap kesiapsiagaan bencana banjir berdada pada kategori baik. Akan tetapi, ketika ditinjau dari aspek sikap, ternyata sikap guru di SDN Gebangmalang Kecamatan Mojoanyar Kabupaten Mojokerto terhadap kesiapsiagaan bencana banyak yang bersikap negatif dengan status kesiapsiagaan bencana tidak siap. Mengacu pada dua penelitian yang telah diuraikan, maka dapat dilihat bahwa penelitian tersebut lebih fokus pada kesiapsiagaan komunitas sekolah dalam penerapan sekolah siaga bencana dan kesiapsiagan sekolah terhadap potensi bencana. Sementara itu, dalam penelitian ini fokus pada bagaimana tingkat kesiapan guru dalam menerapkan materi kebencanaan pada proses pembelajaran.

Berdasarkan uraian di atas, penelitian ini diperlukan mengingat kondisi Indonesia yang memiliki potensi bencana cukup besar dan berpotensi menimbulkan banyak korban jiwa, khususnya anak-anak 
usia sekolah, maka diperlukan kesiapan guru dalam menerapkan materi kebencanaan di sekolah. Dengan demikian, diharapkan korban jiwa dari kalangan anak-anak usia sekolah dapat dikurangi. Adapun tujuan dari penelitian ini yaitu untuk mengetahui kesiapan guru dalam menerapkan materi kebencanaan di sekolah, selain itu penelitian ini juga bertujuan untuk mengetahui pengaruh umur dan tingkat pendidikan guru dalam menerpakan materi kebencanaan di sekolah.

\section{METODE PENELITIAN}

Penelitian ini dilaksanakan pada tanggal 3-6 November 2019 di Kabupaten Klaten khususnya di Kecamatan Wedi dan Kecamatan Bayat dengan sasaran penelitian ini adalah seluruh guru yang mengajar di SMP Muhammadiyah 7 Bayat, MTS Muhammadiyah 10 Wedi, SMK Muhammadiyah 1 Wedi dan SMK Muhammadiyah 2 Wedi. Untuk lebih jelasnya, lokasi penelitian dapat dilihat pada peta sebagaimana ditampilkan pada gambar 1 .

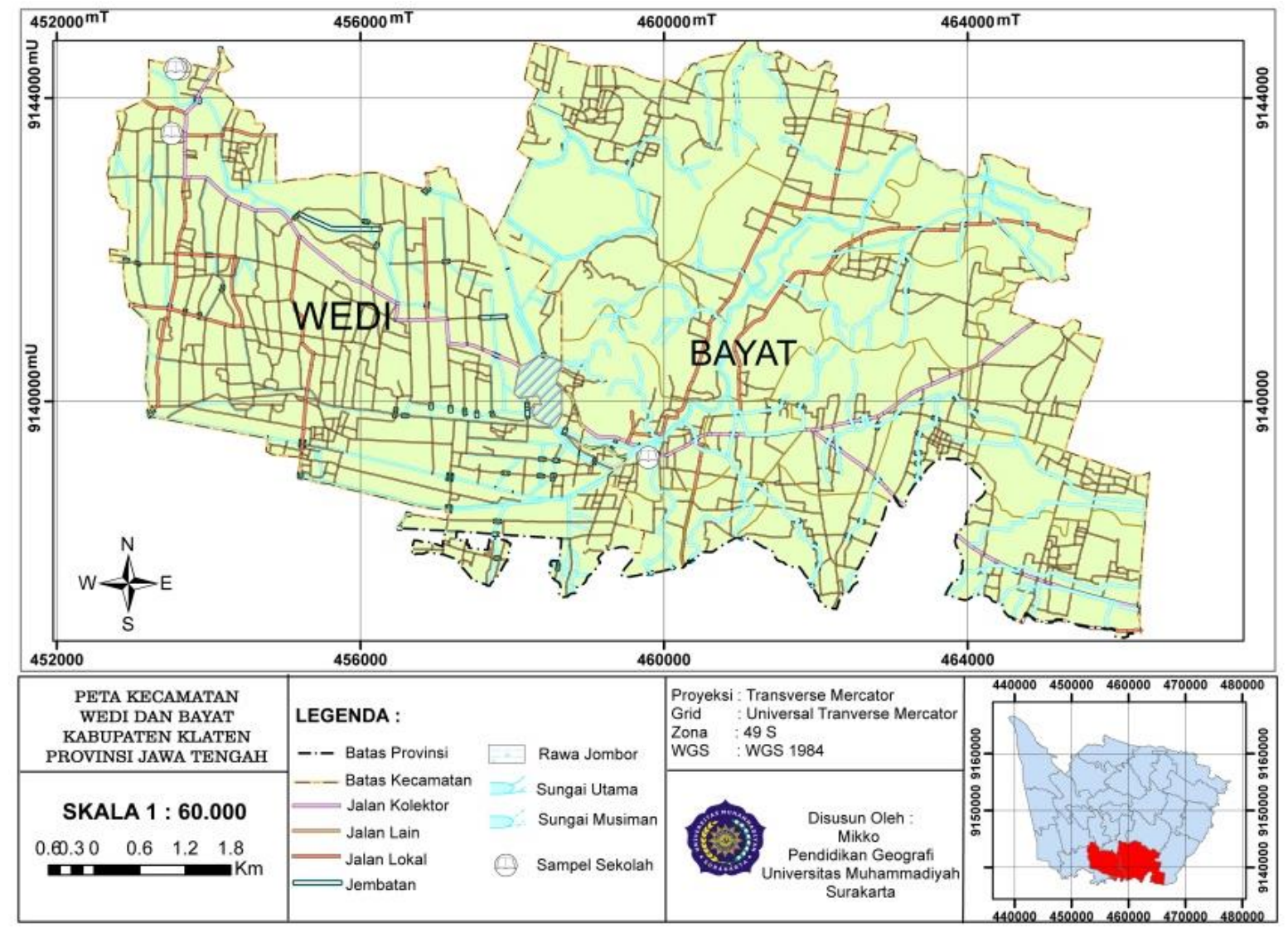

Gambar 1. Peta Kecamatan Bayat dan Kecamatan Wedi

(Sumber: Peneliti, 2019)

Penelitian ini menggunakan pendekatan deskriptif kuantitatif. Pengumpulan data penelitian dilakukan dengan metode observasi, wawancara dan penyebaran kuesioner. Kuesioner merupakan teknik mengumpulkan data yang dilakukan dengan cara memberi seperangkat pertanyaan atau pernyataan tertulis kepada responden untuk dijawabnya (Sugiyono, 2010). Responden dalam penelitian ini adalah guru-guru yang menerapkan atau mengajarkan materi kebencanaan di sekolah, khususnya di Kabupaten Kelaten. Instrumen yang digunakan dalam penelitian ini adalah instrumen utama dan instrumen pendukung untuk mengetahui kesiapan guru dari faktor umur dan tingkat pendidikannya. Teknik analisis data yang digunakan ialah teknik analisis deskriptif kuantitatif, dengan persentase kesiapan guru dalam menerapkan materi kebencanaan di sekolah. Pelaksanaan secara sistematik dilakukan berdasarkan perencanaan, observasi awal, perizinan, pengumpulan data, dan evaluasi. 


\section{TEMUAN DAN PEMBAHASAN}

Pada penelitian ini, temuan dan pembahasan dapat dijabarkan dalam tiga bagian. Pertama, pembahasan hasil perdasarkan variabel yang digunakan dalam penlitian yaitu kesiapan guru dalam menerapkan materi kebencanaan dalam proses pembelajaran di sekolah daerah rawan bencana. kedua, pengaruh tingkat pendidikan guru dalam kesiapan menerapkan materi kebencanaan pada proses pembelajaran, dan ketiga, pengaruh umur guru dalam kesiapan menerapkan materi kebencanaan pada proses pembelajaran di sekolah.

\section{Kesiapan guru dalam menerapkan materi kebencanaan pada proses pembelajaran}

Hasil analisis mengenai tingkat kesiapan guru dalam menerapkan materi kebencanaan pada proses pembelajaran dapat dilihat pada diagram batang pada gambar 2 .

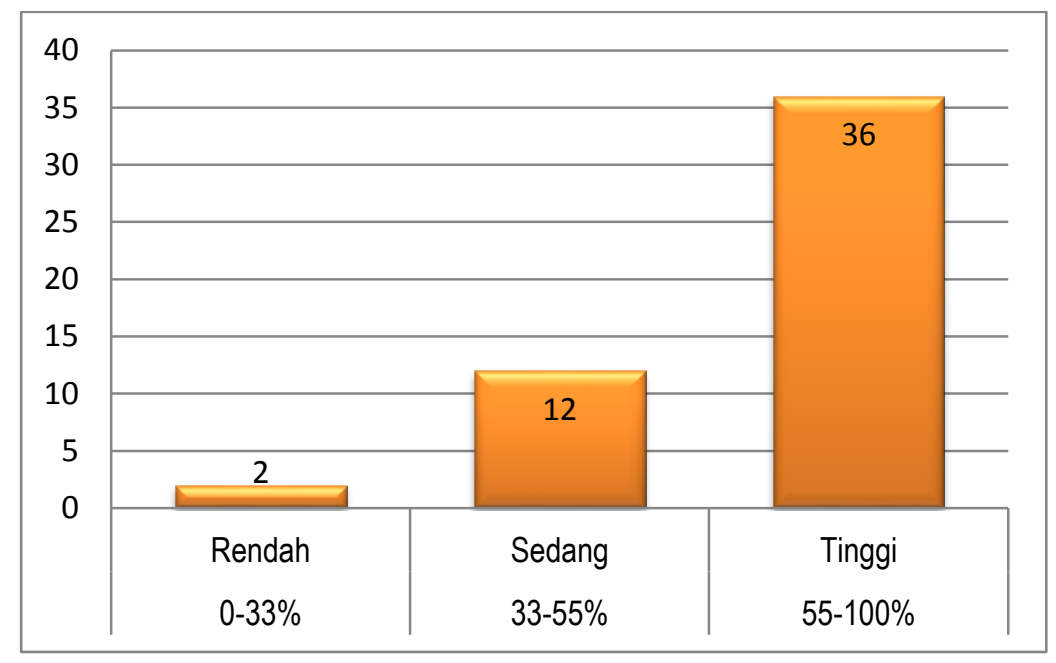

Gambar 2. Tingkat kesiapan guru dalam menerapkan materi kebencanaan (Sumber: Data primer peneliti, 2019)

Gambar 2 di atas merupakan grafik tingkat kesiapan guru dalam menerapkan materi Kebencanaan pada proses pembelajaran. Dari data tersebut dapat dilihat bahwa kesiapan guru berada pada kategori tinggi. Hal ini dibuktikan dari 50 guru, terdapat 36 guru yang memiliki kesiapan terhadap penerapan materi kebencanaan yang termasuk pada rentang persentase $55-100 \%$. Kemudian 12 guru memiliki tingkat kesiapan yang sedang dengan rentang persentase $33-55 \%$ dalam menerapkan materi kebencanaan dan 2 guru yang memiliki kesiapan rendah $(<33 \%)$. Jadi, kesiapan guru dalam menerapkan materi kebencanaan tinggi dengan jumlah 36 guru dengan persentase sebesar $72 \%$. Dilihat dari penjelasan di atas, bahwa kesiapan guru di setiap sekolah memiliki kesiapan yang tinggi, karena sekolah yang berada di Kabupaten Klaten telah menerapkan kebijakan Pengurangan Resiko Bencana.

\section{Uji Statistik Regresi}

Uji statistik yang dilakukan dalam penelitian ini menggunakan aplikasi SPSS guna mempermudah peneliti dalam mendapatkan hasil penelitian. Dalam penelitian ini menggunakan uji asumsi klasik dan uji regresi. Uji Asumsi Klasik berupa uji normalitas yaitu uji yang digunakan untuk mengetahui apakah variabel yang akan dianalisis dalam penelitian ini berdistribusi normal atau tidak. 
Tabel 1. Hasil Uji Normalitas Variabel Umur

One-Sample Kolmogorov-Smirnov Test

\begin{tabular}{|ll|r|}
\hline & & $\begin{array}{r}\text { Unstandardized } \\
\text { Residual }\end{array}$ \\
\hline $\mathrm{N}$ & Mean & 50 \\
Normal Parameters & .0000000 \\
& Std. Deviation & 16.40757120 \\
Most Extreme Differences & Absolute & .072 \\
& Positive & .060 \\
& Negative & -.072 \\
Test Statistic & & .072 \\
Asymp. Sig. (2-tailed) & & $.200^{c, d}$ \\
\hline
\end{tabular}

Sumber: Peneliti, 2019.

Berdasarkan tabel 1 hasil pengujian dari variable penelitian dapat disimpulkan bahwa residu pada variable yang di uji yaitu variabel umur berdistribusi normal karena memiliki nilai 0.200 yang lebih besar dari 0.05 .

Tabel 2. Hasil Uji Normalitas Tingkat Pendidikan

One-Sample Kolmogorov-Smirnov Test

\begin{tabular}{|ll|r|}
\hline & & $\begin{array}{c}\text { Unstandardized } \\
\text { Residual }\end{array}$ \\
\hline $\mathrm{N}$ & Mean & 50 \\
Normal Parameters ${ }^{\mathrm{a}, \mathrm{b}}$ & Std. Deviation & .0000000 \\
Most Extreme Differences & Absolute & 16.99107176 \\
& Positive & .119 \\
& Negative & .112 \\
Test Statistic & & -.119 \\
Asymp. Sig. (2-tailed) & & .119 \\
\hline
\end{tabular}

Sumber : Peneliti, 2019.

Berdasarkan tabel 2, hasil pengujian dari variable penelitian dapat disimpulkan bahwa residu pada variable yang di uji yaitu tingkat pendidikan berdistribusi normal karena memiliki nilai 0.076 yang lebih besar dari 0.05. kemudian, Uji multikoliniearitas dilakukan untuk mengetahui ada atau tidaknya korelasi yang tinggi antara variabel-variabel penelitian. Pengambilan keputusan yang digunakan pada uji ini oleh peneliti ialah menggunakan nilai Variance Inflation Factors (VIF), apabila nilai VIF, jika VIF < 10 maka tidak terjadi multikolinearitas kemudian apabila VIF > 10 maka terjadi multikolinearitas antar variabel penelitian (Siswandari, 2015). Hasil uji multikoliniearitas pada variabel Umur dan Tingkat Pendidikan dalam penelitian ini ditunjukan pada tabel 3 berikut :

Tabel 3. Hasil Uji multikolinearitas Umur Coefficients $^{\mathrm{a}}$

\begin{tabular}{|c|c|c|c|c|c|c|c|}
\hline \multirow[b]{2}{*}{ Model } & \multicolumn{2}{|c|}{$\begin{array}{c}\text { Unstandardized } \\
\text { Coefficients }\end{array}$} & \multirow{2}{*}{$\begin{array}{c}\begin{array}{c}\text { Standardized } \\
\text { Coefficients }\end{array} \\
\text { Beta }\end{array}$} & \multirow[b]{2}{*}{$t$} & \multirow[b]{2}{*}{ Sig. } & \multicolumn{2}{|c|}{ Collinearity Statistics } \\
\hline & $B$ & Std. Error & & & & Tolerance & VIF \\
\hline $1 \quad$ (Constant) & 60.356 & 11.331 & & 5.326 & .000 & & \\
\hline Umur & .516 & .254 & .282 & 2.035 & .047 & 1.000 & 1.000 \\
\hline
\end{tabular}

Sumber : Peneliti, 2019. 
Berdasarkan tabel 3 hasil pengujian dari variabel penelitian dapat disimpulkan bahwa nilai VIF pada variabel yang di uji memiliki nilai 1.000 yang lebih kecil dari 10 sehingga tidak terjadi multikolinearitas antara umur dengan kesiapan guru dalam menerapkan materi kebencanaan.

Tabel 4. Hasil uji multikolinearitas Tingkat Pendidikan

Coefficients $^{\mathrm{a}}$

\begin{tabular}{|c|c|c|c|c|c|c|c|}
\hline \multirow[b]{2}{*}{ Model } & \multicolumn{2}{|c|}{$\begin{array}{l}\text { Unstandardized } \\
\text { Coefficients }\end{array}$} & \multirow{2}{*}{$\begin{array}{c}\text { Standardized } \\
\text { Coefficients }\end{array}$} & \multirow[b]{2}{*}{$\mathrm{t}$} & \multirow[b]{2}{*}{ Sig. } & \multicolumn{2}{|c|}{$\begin{array}{l}\text { Collinearity } \\
\text { Statistics }\end{array}$} \\
\hline & $B$ & Std. Error & & & & Tolerance & VIF \\
\hline $1 \quad$ (Constant) & 72.456 & 13.479 & & 5.375 & .000 & & \\
\hline Tingkat_pendidikan & 2.725 & 3.453 & .113 & .789 & .434 & 1.000 & 1.000 \\
\hline
\end{tabular}

Sumber : Peneliti, 2019.

Berdasarkan tabel 4 hasil pengujian dari variable penelitian dapat disimpulkan bahwa nilai VIF pada variable yang diuji memiliki nilai 1.000 yang lebih kecil dari 10 sehingga tidak terjadi multikolinearitas antara tingkat pendidikan dengan kesiapan guru dalam menerapkan materi kebencanaan. Uji autokorelasi dilakukan untuk mengetahui apakah ada model regresi yang berkorelasi. Pada penelitian ini, peneliti menggunakan data residu untuk mewakili data yang akan dianalisis. Telah dijelaskan bahwa mendeteksi otokorelasi memiliki cara yaitu menggunakan statistik Durbin-Watson, dengan pengambilan keputusan berdasarkan $\mathrm{H}_{0}$ ditolak pada a tertentu jika $\mathbf{d}<\mathrm{d}_{\mathrm{L}}$, hal ini berarti bahwa terjadi otokorelasi positif dalam residu. Jika $\mathrm{d}_{\mathrm{L}} \leq \mathbf{d} \leq \mathrm{d}_{\mathrm{u}}$ maka tidak ada keputusan yang dapat diambil atau dengan kata lain hasil pengujian ini tidak meyakinkan. Hasil uji autokorelasi pada variabel Umur dan Tingkat Pendidikan dalam penelitian ini ditunjukan pada table 4.

Tabel 4. Hasil uji autokorelasi umur

Model Summary

\begin{tabular}{|c|c|c|c|c|c|}
\hline Model & $\mathrm{R}$ & $\mathrm{R}$ Square & $\begin{array}{c}\text { Adjusted } \mathrm{R} \\
\text { Square }\end{array}$ & $\begin{array}{c}\text { Std. Error of the } \\
\text { Estimate }\end{array}$ & Durbin-Watson \\
\hline 1 & $.282^{\mathrm{a}}$ & .079 & .060 & 16.578 & .847 \\
\hline
\end{tabular}

Sumber : Peneliti, 2019.

Jika dasar asumsi sebagaimana yang terdapat di atas dan hasil pengolahan data terdapat nilai sebagai berikut :

\begin{tabular}{|c|c|c|c|c|}
\hline $\mathrm{d}$ & $\mathrm{dl}$ & $\mathrm{du}$ & $4-\mathrm{dl}$ & $4-\mathrm{du}$ \\
\hline 0.847 & 1.5035 & 1.5849 & 2.4965 & 2.4151 \\
\hline
\end{tabular}

Berdasarkan hasil dari tabel 4 maka hasil uji autokorelasi berbunyi "terdapat autokorelasi" antara umur seorang guru dengan kesiapannya dalam mengajarkan materi kebencanaan dalam kelas, karena $\mathrm{d}<\mathrm{dl}=0.847<1.5035$.

Tabel 5. Hasil uji autokorelasi tingkat pendidikan

Model Summary

\begin{tabular}{|c|c|c|c|c|c|}
\hline Model & $R$ & $R$ Square & $\begin{array}{c}\text { Adjusted } R \\
\text { Square }\end{array}$ & $\begin{array}{c}\text { Std. Error of the } \\
\text { Estimate }\end{array}$ & Durbin-Watson \\
\hline 1 & $.113^{a}$ & .013 & -.008 & 17.167 & .899 \\
\hline
\end{tabular}

Sumber : Peneliti, 2019. 
Jika dasar asumsi sebagaimana yang terdapat di atas dan hasil pengolahan data terdapat nilai sebagai berikut :

\begin{tabular}{|c|c|c|c|c|}
\hline $\mathrm{d}$ & $\mathrm{dl}$ & $\mathrm{du}$ & $4-\mathrm{dl}$ & $4-\mathrm{du}$ \\
\hline 0.889 & 1.5035 & 1.5849 & 2.4965 & 2.4151 \\
\hline
\end{tabular}

Berdasarkan hasil dari tabel 5 maka hasil uji autokorelasi berbunyi "terdapat autokorelasi" antara tingkat pendidikan seorang guru dengan kesiapannya dalam mengajarkan materi kebencanaan dalam kelas, karena $\mathrm{d}<\mathrm{dl}=0.899<1.5035$.

Selanjutnya dilakukan uji regresi yang merupakan langkah dalam penelitian untuk menganalisis adakah hubungan yang berpengaruh antara variabel bebas dan variable terikat. Dalam uji ini apabila asumsi-asumsi yang ada dalam penelitian tidak terpenuhi maka hasil analisis data dari penelitian akan kehilangan makna. Dalam uji regresi ini peneliti mengambil beberapa kesimpulan dari data yang telah di uji, sebagai berikut :

a. Umur

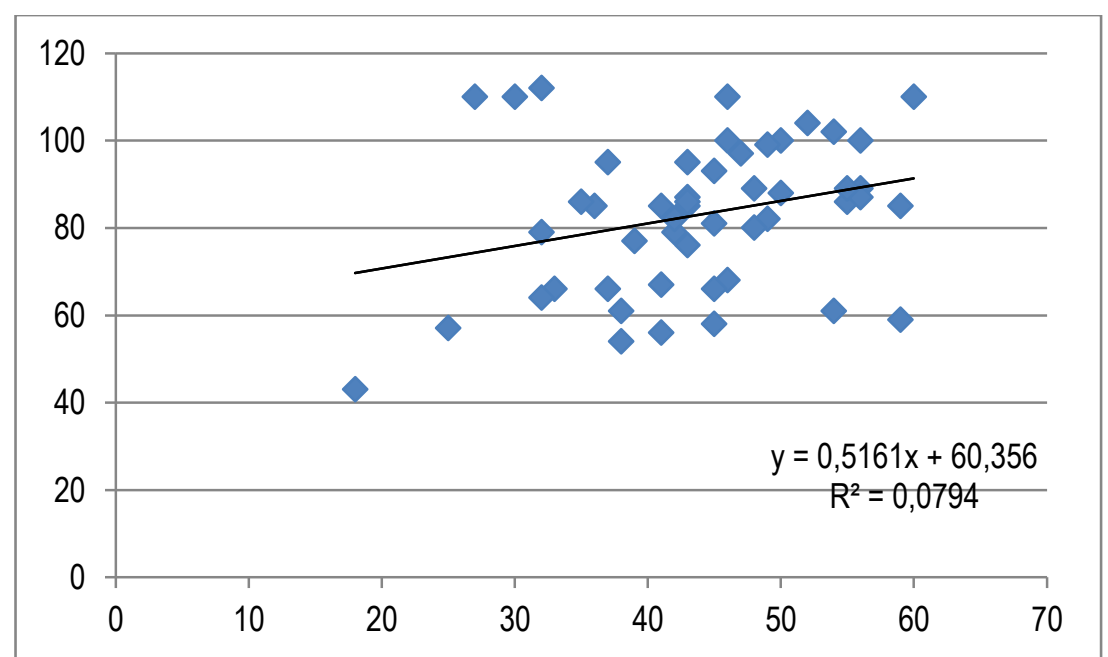

Gambar 3. Hasil Regresi Umur dalam kesiapan menerapkan materi kebencanaan

(Sumber : Peneliti, 2019)

Gambar 3 merupakan hasil regresi umur dalam kesiapan menerapkan materi kebencanaan memiliki hasil persamaan regresi yaitu : $y=0,5161 x+60,356$. Kemudian besarnya pengaruh antara variabel $X$ dan variabel $Y$ dengan ditunjukan dengan hasil $R^{2}=0,0794$. Dari hasil nilai $R$-sq $<0,5$ yang berarti pengaruh antara umur seorang guru dengan kesiapan dalam menerapkan materi kebencanaan lemah. 
b. Tingkat Pendidikan

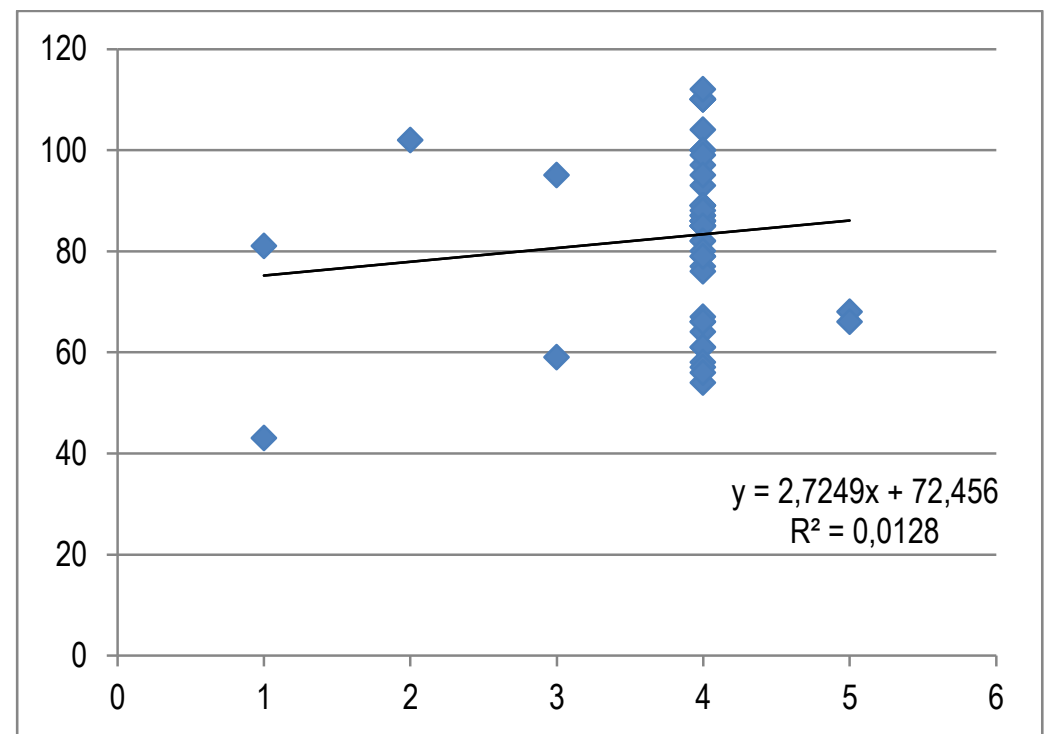

Gambar 4. Hasil Regresi Umur dalam kesiapan menerapkan materi kebencanaan.

(Sumber : Peneliti, 2019)

Gambar 4 merupakan hasil regresi umur dalam kesiapan menerapkan materi kebencanaan memiliki hasil persamaan regresi yaitu : $y=2,7249 x+72,456$. Kemudian besarnya pengaruh antara variabel $X$ dan variabel $Y$ dengan ditunjukan dengan hasil $R^{2}=0,0128$. Dari hasil nilai $R$-sq $<0,5$ yang berarti pengaruh antara umur seorang guru dengan kesiapan dalam menerapkan materi kebencanaan lemah. Selain menggunakan data uji regresi di atas peneliti juga menggunakan data lain yang berasal dari SPSS, seperti berikut:

a. Umur

Tabel 6. Hasil uji regresi umur

\section{Coefficients $^{\mathrm{a}}$}

\begin{tabular}{|c|c|c|c|c|c|}
\hline \multirow{2}{*}{ Model } & \multicolumn{2}{|c|}{ Unstandardized Coefficients } & $\begin{array}{c}\text { Standardized } \\
\text { Coefficients }\end{array}$ & \multirow{2}{*}{$\mathrm{t}$} & \multirow{2}{*}{ Sig. } \\
\cline { 2 - 4 } & $\mathrm{B}$ & Std. Error & Beta & & \\
\hline \multirow{2}{*}{1 (Constant) } & 60.356 & 11.331 & & 5.326 & .000 \\
Umur & .516 & .254 & .282 & 2.035 & .047 \\
\hline
\end{tabular}

Sumber : Peneliti, 2019.

Berdasarkan tabel 6 diatas hasil uji regresi umur memiliki nilai signifikansi dari tabel Coefficients diperoleh nilai $0.047<0.05$ sehingga dapat disimpulkan bahwa variabel umur $(X)$ berpengaruh terhadap variabel tingkat kesiapan $(Y)$. Selain itu, nilai $t$ : diketahui nilai $t$ hitung sebesar $2.035>t$ tabel 2.011 sehingga dapat disimpulkan bahwa variabel umur $(X)$ berpengaruh terhadap variabel tingkat kesiapan $(\mathrm{Y})$. 


\section{b. Tingkat Pendidikan}

Tabel 7. Hasil uji regresi tingkat pendidikan

\section{Coefficients $^{\mathrm{a}}$}

\begin{tabular}{|c|c|c|c|c|c|c|}
\hline & \multirow[t]{2}{*}{ Model } & \multicolumn{2}{|c|}{$\begin{array}{c}\text { Unstandardized } \\
\text { Coefficients }\end{array}$} & $\begin{array}{c}\text { Standardized } \\
\text { Coefficients } \\
\end{array}$ & \multirow[t]{2}{*}{$\mathrm{t}$} & \multirow[t]{2}{*}{ Sig. } \\
\hline & & $B$ & Std. Error & Beta & & \\
\hline \multirow{2}{*}{1} & (Constant) & 72.456 & 13.479 & & 5.375 & .000 \\
\hline & tingkat_pendidikan & 2.725 & 3.453 & .113 & .789 & .434 \\
\hline
\end{tabular}

Sumber : Peneliti, 2019.

Berdasarkan tabel 7 di atas hasil uji regresi tingkat pendidikan memiliki nilai signifikansi dari tabel Coefficients diperoleh nilai $0.434<0.05$ sehingga dapat disimpulkan bahwa variabel umur $(\mathrm{X})$ tidak berpengaruh terhadap variabel tingkat kesiapan $(Y)$. Selain itu nilai $t$ : diketahui nilai $t$ hitung sebesar $0.789>t$ tabel 2.011 sehingga dapat disimpulkan bahwa variabel umur $(X)$ tidak berpengaruh terhadap variabel tingkat kesiapan $(\mathrm{Y})$.

\section{SIMPULAN}

Dalam penelitian ini dapat diambil kesimpulan bahwa kesiapan seorang guru untuk menerapkan materi kebencanaan di sekolah Kabupaten Klaten. Bahwa tingkat kesiapan guru dalam menerapkan materi kebencanaan di sekolah yaitu SMP Muhammadiyah 7 Bayat, MTS Muhammadiyah 10 Wedi, SMK Muhammadiyah 1 Wedi dan SMK Muhammadiyah 2 Wedi berada pada kategori tinggi dengan persentase $72 \%$. Hal ini dikarenakan sudah adanya kebijakan tentang materi kebencanaan yang harus diterapkan di Kabupaten Klaten untuk mengurangi banyaknya korban jiwa di sekolah.

Selain itu, terdapat pengaruh antara umur dengan kesiapan guru dalam menerapkan materi kebencanaan di SMP Muhammadiyah 7 Bayat, MTS Muhammadiyah 10 Wedi, SMK Muhammadiyah 1 Wedi dan SMK Muhammadiyah 2 Wedi. Sedangkan pada tingkat pendidikan tidak ada pengaruh dengan kesiapan guru dalam menerapkan materi kebencanaan di SMP Muhammadiyah 7 Bayat, MTS Muhammadiyah 10 Wedi, SMK Muhammadiyah 1 Wedi dan SMK Muhammadiyah 2 Wedi dengan ditunjukan oleh uji regresi yang telah dilakukan.

\section{DAFTAR PUSTAKA}

Aprilin, H., Haksama, S. \& Makhfludi. (2018). Kesiapsiagaan Sekolah Terhadap Potensi Bencana Banjir di SDN Gebangmalang Kecamatan Mojoanyar Kabupaten Mojokerto. Jurnal Biosains Pascasarjana. 20 (2): 1-13.

Hafida, S.H.N. (2018). Urgensi Pendidikan Kebencanaan Bagi Siswa Sebagai Upaya Mewujudkan Generasi Tangguh Bencana. Jurnal Pendidikan dan IImu Sosial. 28(2): 1-10.

Honesti, L. \& Djali, N. (2012). Pendidikan Kebencanaan di Sekolah-Sekolah di Indonesia Berdasarkan Beberapa Sudut Pandang Disiplin Ilmu Pengetahuan. Jurnal Momentum. 12(1): 51-56.

Lesmana, C. \& Purborini, N. (2015). Kesiapsiagaan Komunitas Sekolah Dalam Menghadapi Bencana di Kabupaten Magelang. Jurnal Teknik Sipil. 11(1): 15-28.

Reeves, M. A., Kanan L.M., \& Plog, A.E. (2010). Comprehensive planning for safe learning environments: A school professional's guide to integrating physical and psychological safety, prevention through recovery. New York. London : Routledge.

Republik Indonesia. (2007). Undang-Undang Nomor 24 tahun 2007 tentang penanggulangan bencana. Lembaran Negara RI tahun 2007. 
Setyowati, S., Hadi, B.S., dan Ashari, A. (2013). Pengembangan Sistem Informasi Bahaya Erupsi Untuk Pengelolaan Kebencanaan Di Lereng Selatan Gunungapi Merapi. Jurnal Majalah Geografi Indonesia. 27(2): 138-148.

Siswandari. (2015). Statistika Computer Based . Surakarta: UNS Press.

Sugiyono. (2010). Metode Penelitian Administrasi Dilengkapi dengan Metode R\&D. Bandung: Alfabeta. 